Agus Setiawan: Guru Berkarakter di Era Milenial (Perspektif Habib Abdullah Bin Alawi Al-Haddah)

Al Qalam: Jurnal Ilmiah Keagamaan dan Kemasyarakatan

Vol. 13, No. 2, 2019

P-ISSN: 1907-4174; E-ISSN: 2621-0681

\title{
GURU BERKARAKTER DI ERA MILENIAL (Perspektif Habib Abdullah bin Alawi Al-Haddah)
}

Oleh:

Agus Setiawan

Institut Agama Islam Negeri Samarinda, Indonesia

agus.rdat@gmail.com

\begin{abstract}
Abstrak
Penelitian ini bertujuan untuk mendeskripsikan secara konseptual guru yang berkarakter secara Islami di era millenial. Jenis dalam penelitian ini adalah penelitian pustaka (Library research). Penelitian ini menggunakan data primer adalah buku karya Al-Habib Abdullah bin Alawi Al-Haddad yaitu Adab Suluk al-Murid. Penelitian ini juga menggunakan pendekatan berparadigma diskriptif kualitatif. Hasil penelitian mengemukakan bahwa karakter guru perspektif Al-Habib Abdullah bin Alawi Al-Haddad yaitu niat yang tulus, taubatan yang sesunggunya, menjaga dari perbuatan maksiat, beribadah meluangkan waktu kepada Allah, dzikir dan tafakur setiap saat, jauhi sifat malas, kesabaran dalam segala hal, bersedekah, dan berlaku sosial kepada manusia dan jangan dengki kepada makhluk Allah. Artikel ini menyimpulkan bahwa beberapa temuan dalam kajian kitab sebagai pandangan Al-Habib Abdullah adalah dapat diimplementasikan pada era millennial saat ini. Implikasinya bahwa perspektif Al-Habib Abdullah memberikan gambaran bahwa dunia pendidikan saat ini sangat membutuhkan karakter guru yang demikian, sehingga dalam proses pendidikan akan berdampak manfaat bagi anak didik. Penelitian ini juga dapat memberikan khazanah keilmuan bagi dunia pendidikan dan guru khususnya, juga bagi peneliti lain yang akan menggali lebih lanjut mengenai perspektif Al-Habib Abdullah dalam bidang lain.
\end{abstract}

Kata Kunci: Guru, Pendidikan Karakter, Adab Suluk al-Murid, Era Millenial 
Agus Setiawan: Guru Berkarakter di Era Milenial (Perspektif Habib Abdullah Bin Alawi Al-Haddah)

\section{A. Pendahuluan}

Ternyata pendidikan moral dan pendidikan karakter tidaklah sama. Perbedaannya terletak pada ruang lingkup dan lingkungan yang membantu individu dalam mengambil keputusan. Dalam pendidikan moral, ruang lingkupnya adalah kondisi batin seseorang. Sedangkan dalam pendidikan karakter ruang lingkupnya selain terdapat dalam diri individu, juga memiliki konsekuensi kelembagaan, yang keputusannya tampil dalam kinerja dan kebijakan lembaga pendidikan. ${ }^{1}$ Maka, secara esensinya bawha pendidikan karakter adalah suatu usaha sengaja untuk membantu orang memahami, peduli dan bertindak menurut nilai-nilai etika. Pendidikan karakter memiliki esensi dan makna yang sama dengan pendidikan moral dan pendidikan akhlak. Tujuannya adalah membentuk pribadi anak, supaya menjadi manusia yang baik, warga masyarakat, dan warga negara yang baik.

Dalam konteks Indonesia, Kemendiknas secara detail menyebutkan delapan belas nilai dalam pendidikan karakter, yaitu religius, jujur, toleransi, disiplin, kerja keras, kreatif, mandiri, demokratis, rasa ingin tahu, semangat kebangsaan, cinta tanah air, menghargai prestasi, bersahabat/komunikatif, gemar membaca, peduli lingkungan, dan peduli sosial, serta tanggung jawab. $\mathrm{Koesoema}^{2}$ mengambil garis besarnya saja dengan menyebutkan delapan nilai, yakni keutamaan, keindahan, kerja, cinta tanah air, demokrasi, kesatuan, menghidupi nilai moral, dan kemanusiaan.

Dalam pendidikan karakter, guru memiliki peranan yang sangat penting yaitu tidak hanya sebagai pemberi materi pelajaran, namun yang lebih utama adalah sebagai tauladan. Di beberapa media, karakter guru sudah tercoreng dengan adanya penyimpangan moral, sehingga ini menjadi perhatian untuk membentuk kembali karakter guru secara Islami. Dalam Islam bahwa guru idealnya menjadi contoh pembentukan karakter bangsa, juga agama. Dengan

${ }^{1}$ Doni Koesoema A, Pendidikan Karakter: Strategi Mendidik Anak di Zaman Global (Jakarta: Grasindo, 2007), h. 198.

${ }^{2}$ Doni A. Koesoema, Pendidikan Karakter:.., h. 208-211 
Agus Setiawan: Guru Berkarakter di Era Milenial (Perspektif Habib Abdullah Bin Alawi Al-Haddah)

karakter tersebut, guru akan menjadi contoh bagi anak didiknya dalam kehidupan sehari-hari.

Menjadi seorang guru yang berkarakter bukan pekerjaan mudah, perlu pedoman yang harus diikuti dan konsistensi diri. Pedoman tersebut menurut penulis, salah satunya ada pada kitab Adab Suluk Al-Murid. Kitab Adab Sulukul Murid merupakan karya dari al-Imam al-Habib Abdullah bin Alwi al-Haddad. Judul asli kitab ini adalah Risalah Adab Sulukul Murid. Habib Abdullah merupakan tokoh yang banyak berpengaruh di Indonesia dengan Ratib AlHaddadnya. Kitab ini mempunyai konsep yang luar biasa bagi seorang murid juga guru. Kitab ini menjadi bagian yang semestinya dimiliki oleh guru dan murid apabila ingin mempunyai karakter Islami. Artikel ini selanjutnya hanya akan mencermati secara konsep mengenai guru yang berkarakter. Bisa menjadi ikhtiar menciptakan guru berkarakter di era milenial saat ini.

\section{B. Metodologi Penelitian}

Secara metodologis penelitian ini menggunakan pendekatan analisis kritis, karena dalam penelitian ini menyangkut karakter-karakter guru yang akan dipaparkan dan diaplikasikan untuk seorang guru atau pengajar pada umumnya. Penelitian ini juga menggunakan pendekatan berparadigma diskriptif kualitatif. Kajian ini berdasarkan kajian kepustakaan (library reseach) data diambil dari kepustakaan baik berupa buku, dokumen maupun artikel. ${ }^{3}$ Penelitian ini dimaksud untuk menyingkap dan mencari karakter-karakter guru dalam buku Adab Suluk al-Murid tulisan Al-Habib Abdullah bin Alawi Al-Haddad untuk diimplementasikan kepada pendidik. Dengan demikian, penelitian ini tergolong dalan jenis penelitian dasar (basic research).

${ }^{3}$ Sugiyono, Metode Penelitian \& Pengembangan (Research and Development) (Bandung: Alfabeta, 2017), 95.

Al Qalam: Jurnal Ilmiah Keagamaan dan Kemasyarakatan Vol. 13, No. 2, Juli-Desember 2019 
Agus Setiawan: Guru Berkarakter di Era Milenial (Perspektif Habib Abdullah Bin Alawi Al-Haddah)

\section{Hasil Penelitian dan Pembahasan}

\section{Hasil Temuan}

Beberapa temuan penelitian perspektif Al-Habib Abdullah Al-Haddad mengenai karakter guru yang bisa diaplikasikan pada era milenial saat ini adalah: Karakteristik pemikiran Al-Habib Abdullah dalam kitab tersebut dapat digolongkan dalam corak praktis yang tetap berpegang teguh pada Al-Qur'an dan Hadis. Kecenderungan pemikiran yang menonjol dari Al-Habib Abdullah dalam kitab Adab Suluk Murid adalah mengetengahkan nilai-nilai etis yang bernafaskan sufistik diantaranya adalah niat, taubat, menjaga hati dari penyakit, qonaah dan pemaaf.

\section{a. Niat}

Hendaklah seorang guru itu meluruskan niatnya terlebih dahulu sebelum menyampaikan ilmu kepada murid-muridnya dan berusaha terus menerus memperbaharui niatnya karena niat itu adalah asas pertama dalam mengerjakan suatu pekerjaan. Sebagaimana perkataan al-habib Abdullah dalam kitab Risalah Muawanah "Niat adalah asas utama dalam sebuah perbuatan dan semua amal perbuatan akan mengikutinya, baik atau buruknya dan benar maupun tidaknya. ${ }^{4}$

Dan hal ini sesuai dengan yang telah baginda Nabi Muhammad Saw sabdakan

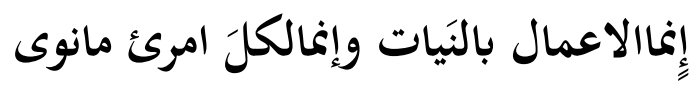

Artinya : "Sesungguhnya segala sesuatu perbuatan itu tergantung pada niat dan sesungguhnya tiap-tiap orang akan mendapatkan apa yang ia niatkan",

${ }^{4}$ Al-Habib Abdullah bin Alawi al-Haddad, Risalah Mu'awanah Terj Ahmad Yunus al-Muhdhar Nasehat untukmu Wahai Saudaraku (Surabaya: Cahaya Ilmu, 2015), h. 23 .

${ }^{5}$ Imam Nawawi, al-Arba'in Nawawiyah Terj Yunan Abduh Hadis ar-Arba;in Annawawiyah (Surakarta: Media Insani, 2007), h. 10. 
Agus Setiawan: Guru Berkarakter di Era Milenial (Perspektif Habib Abdullah Bin Alawi Al-Haddah)

Oleh sebab itu, tidaklah seseorang guru itu mengucapkan sutu perkataan atau melakukan satu perbuatan atau merencanakan sesuatu apapun, kecuali sudah berniat untuk mendekatkan diri kepada Allah swt dan menginginkan pahalanya yang telah diatur oleh Allah st pada perkara yang diniatkan sebagai bentuk karunia-Nya.

Niat menurut al- Habib Abdullah biasa diartikan salah satu dari dua makna, yaitu:

Pertama, niat itu ibarat tujuan yang mendorong untuk berencana, berkata dan beramal.Niat semacam ini kabanyakannya lebih baik dari amal perbuatannya.

Mengenai hal ini baginda Nabi saw bersabda :

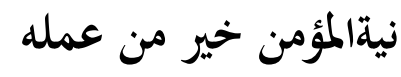

Artinya : "Niat seorang mukmin lebih baik dari perbuatannya."6

Kedua, niat itu ibarat tujuan melakukan sesuatu. Niat semacam ini semacam ini tidak lebih baik dari amal perbuatan tetapi dalam tekadnya untuk melakukan sesuatu seorang manusia.

\section{b. Taubat}

Setelah meluruskan niatnya dalam mengajar, maka hendaklah seorang guru itu memperbaiki taubat kepada Allah swt dari setiap dosa yang kecil maupun yang besar, yang nampak maupun yang tersembunyi karena taubat adalah langkah awal yang harus dimulai seorang salik dalam perjalannya kepada Allah, dan jika ada pada dirinya kezaliman terhadap seseorang, hendaklah ia segera menunaikannya kepada orang-orang yang berhak, jika itu memungkinkan dan jika tidak maka hendaklah ia meminta kerelaan dari mereka. Karena hal itu merupakan dasar dari seluruh maqam dan Allah mencintai orang-orang yang bertaubat.

Dalam hal ini Allah swt berfirman :

\footnotetext{
${ }^{6}$ Qaimmuddin, Durrarul Muhammadiyah (Bangil: Dalwa, 2010).
} 
Agus Setiawan: Guru Berkarakter di Era Milenial (Perspektif Habib Abdullah Bin Alawi Al-Haddah)

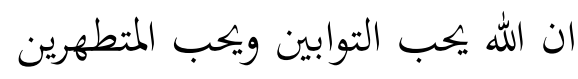

Yang artinya : "sesungguhnya Allah menyukai orang-orang yang bertaubat dan menyukai orang-orang yang menyucikan diri.” (Q.S al-baqarah ayat: 222)

Rasulullah saw bersabda :

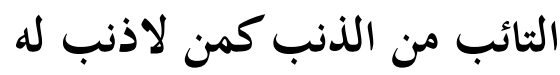

Artinya :" Orang yang bertaubat dari dosa, laksana orang yang tidak berdosa"

Al-habib Abdullah berkata "Orang yang sungguh-sungguh dalam bertaubat memiliki beberapa tanda. Diantarannya adalah hati selalu pilu, banyak menangis, selalu taat, serta menjauhi temab-teman yang jahat, dan tempattempat kemaksiatan.

Al-habib Abdullah berkata "Hendaklah seorang salik menjaga diri dari dosa kecil lebih-lebih dari yang besar, seperti menjaga dirinya dari api yang membakar, air yang menenggelamkan dan racun yang mematikan.

Artinya, seorang guru itu tidak memilih dosa, tidak berniat melakukannya, tidak membicarakannya sebelum terjadi dan tidak bergembira setelah ia terjadi. Jikalau ia terjerumus didalamnya, maka ia harus menutupinya, membecinya, dan segera bertaubat darinya.

Hendaklah seorang guru itu juga memperbaharui taubat dan segera melakukannya setiap waktu. Karena dosa semakin banyak, sedangkan seorang hamba dalam keadaan dzahir dan bathinnya tidak pernah terlepas dari berbagai macam kemaksiatan, meskipun tingkah lakunya baik dan lurus. Dan cukuplah Rosulallah saw menjadi contoh yang merupakan nabi yang ma'sum dan memiliki kesempurnaan yang mutlak, meskipun demikian, beliau saw tetap bertaubat kepada Allah swt dan beristighfar kepadaNya setiap hari lebih dari tujuh puluh kali. Hendaklah memperbanyak istighfar pada tengah hari dan tengah malam, terutama menjelang masuknya waktu subuh. 
Agus Setiawan: Guru Berkarakter di Era Milenial (Perspektif Habib Abdullah Bin Alawi Al-Haddah)

\section{c. Menjaga Hati dari Penyakit}

Hati adalah pemimpin dan pengendali anggota tubuh dan disanalah tempat bercokolnya akidah, budi pekerti, dan niat yang baik maupun yang buruk. $^{7}$ Oleh karena itu, hendaklah seorang guru itu berusaha dalam sungguhsungguh dalam menjaga hatinya dari segala gangguan, penyakit dan lintasan hati yang kotor dan hendaklah pula ia mendirikan tirai dari kewaspadaan pada pintu hatinya yang dapat mencegahnya (gangguan-gangguan) masuk ke dalamnya (hati). Sebab, bila semua itu masuk ke dalam hati, maka akan merusaknya dan setelah itu sulit mengeluarkannya.

Al-Habib Abdullah al-Haddad berkata:"Wahai murid, ketahuilah bahwa hati dapat berbuat maksiat yang lebih keji, lebih buruk dan lebih jahat dari berbagai maksiat yang biasa dilakukan oleh anggota badan. Tentunya hati tersebut tidak dapat menerima ma 'rifat dan kecintaan kepada Allah swt, kecuali setelah segala maksiatnya dijauhi oleh hati, diantaranya adalah sombong, riya', dan hasud." 8

\section{d. Qonaah}

Qana'ah adalah suatu sikap merasa cukup dengan pembagian rizki yang diberikan Allah, dan menyandarkan kebutuhan hanya kepada Allah SWT. Seorang yang qana'ah akan memohon hanya kepada-Nya, tidak kepada yang lain.

Habib Abdullah bin Alwi al-Haddad bersyair: Andai dirimu ridha dengan bagian yang dijatahkan kepadamu, niscaya dirimu hidup penuh kenikmatan. Namun bila dirimu tiada pernah ridha, maka dirimu senantiasa dalam kegundahan.Qana'ah adalah awal dari sikap ridha.Setiap orang yang memiliki sikap qana'ah pasti mendapatkan bagian dari ridha. Sikap qana'ah akan tumbuh bila seseorang cermat dalam berinfak serta tidak berfoya-foya. Dalam sebuah hadits disebutkan, "Orang yang cermat berbelanja akan

7 al-Haddad, Risalah Mu'awanah Terj Ahmad Yunus al-Muhdhar Nasehat untukmu Wahai Saudaraku....h. 226

${ }^{8}$ al-Haddad, Risalah Mu'awanah..., h. 9. 
Agus Setiawan: Guru Berkarakter di Era Milenial (Perspektif Habib Abdullah Bin Alawi Al-Haddah)

dicukupkan kebutuhannya oleh Allah SWT, sedangkan orang yang mubazir akan difakirkan oleh Allah SWT."

Seseorang akan memiliki sikap qana'ah bila ia benar-benar pasrah pada pembagian Allah SWT. Dalam Al-Qur'anul Karim, Allah SWT berfirman:

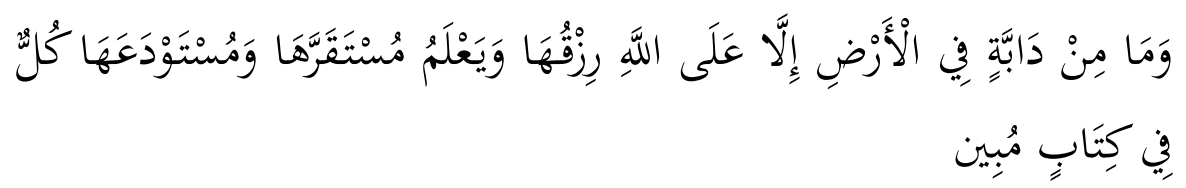

"Dan tidak ada suatu binatang melata pun di bumi melainkan Allah-lah yang memberi rezkinya, dan dia mengetahui tempat berdiam binatang itu dan tempat penyimpanannya. semuanya tertulis dalam Kitab yang nyata (Lauh mahfuzh)." (QS; Hud ayat 6)

Sikap pasrah semacam ini adalah ilmu, cermat berinfak adalah amal. Sementara itu, pondasi qana'ah adalah kesabaran, pendek angan, memahami bahaya kekayaan dan keutamaan qana'ah. Dalam syair yang lain, Habib Abdullah bin Alwi al-Haddad berpesan:

Sungguh, qana'ah adalah harta yang takkan pernah punah. Terapkanlah saudaraku, moga engkau beroleh petunjuk. Hidup dengan qana'ah itu asyik.Hiduplah dengan qana'ah tanpa rasa rakus dan tamak. Engkau akan mulia, berwibawa dan bermartabat luhur.

\section{e. Pemaaf}

Di antara amal-amal shalih yang sangat dianjurkan adalah sifat memaafkan. Islam juga mengajarkan pemeluknya untuk memberi maaf dan menjauhi sifat dendam. Mudah memaafkan, penyayang terhadap sesama muslim dan lapang dada terhadap kesalahan orang merupakan amal shalih yang keutamaannya besar dan sangat dianjurkan oleh Islam. Bahkan sifat ini termasuk ciri hamba Allah SWT yang bertakwa kepadaNya, sebagaimana firman Allah yang artinya : "(yaitu) orang orang yang menafkahkan (hartanya, baik di waktu lapang maupun sempit, dan orang-orang yang menahan 
Agus Setiawan: Guru Berkarakter di Era Milenial (Perspektif Habib Abdullah Bin Alawi Al-Haddah)

amarahnya dan memaafkan (kesalahan) orang. Allah menyukai orang-orang yang berbuat kebajikan". (QS Ali Imran :134)

Salah satu akhlak mulia adalah sifat pemaaf, dan lawan dari sifat ini adalah sifat pemarah dan pendendam. Memberi maaf adalah sifat luhur yang harus ada pada diri setiap muslim. Begitu tingginya nilai memaafkan ini hingga ia mampu membebaskan hukum qishash bagi pembunuh yang mendapat ampunan dari keluarga korban. Karena itulah, Rasulullah SAW secara khusus menggambarkan besarnya keutamaan dan pahala sifat mudah memafkan di sisi Allah dalam sabda beliau, "Tidaklah Allah menambah bagi seorang hamba dengan pemberian maafnya (kepada saudaranya) kecuali kemuliaan dunia dan akhirat." Artinya, bahwa seseorang yang mudah memaafkan akan dimuliakan di dunia dan mendapat pahala yang besar dari Allah SWT.

\section{Pembahasan dan Diskusi}

\section{a. Relevansi Karakter Guru di Era Milenial}

Guru adalah pendidik profesional yang mempunyai tugas utama mendidik, mengajar, membimbing, mengarahkan, melatih, menilai, dan mengevaluasi peserta didik atau siswa. Dalam konteks pencapaian tujuan pendidikan karakter, Guru menjadi ujung tombak keberhasilan tersebut. Guru, sebagai sosok yang digugu dan ditiru, mempunyai peran penting dalam aplikasi pendidikan karakter di sekolah maupun di luar sekolah. Sebagai seorang pendidik, guru menjadi sosok figur dalam pandangan anak, guru akan menjadi patokan bagi sikap anak didik. Dalam Undang-Undang Sistem Pendidikan Nasional diamanatkan bahwa seorang guru harus memiliki kompetensi kepribadian yang baik. Guru adalah para pemimpin, orang tua dan juga pendidik. Guru adalah teladan. Guru adalah "digugu" (didengar) dan "ditiru" (dicontoh). Guru bukan sekedar terampil mengajar bagaimana menjawab soal 
Agus Setiawan: Guru Berkarakter di Era Milenial (Perspektif Habib Abdullah Bin Alawi Al-Haddah)

Ujian Nasional, tetapi diri dan hidupnya harus menjadi contoh bagi muridmuridnya. ${ }^{9}$

Kompetensi kepribadian tersebut menggambarkan sifat pribadi dari seorang guru. Satu yang penting dimiliki oleh seorang guru dalam rangka pengembangan karakter anak didik adalah guru harus mempunyai kepribadian yang baik dan terintegrasi dan mempunyai mental yang sehat. Kriteria untuk guru PAI profesional, profesionalisme mereka tidak hanya berorientasi pada materi tetapi juga diarahkan pada orientasi spiritual. Karena para guru PAI profesional diharapkan dapat mendorong kemajuan masyarakat, terutama di era milenium ini. ${ }^{10}$ Peran guru Islam dalam membimbing moral remaja sehingga dapat menjadi solusi bagi para guru dan untuk mencapai kinerja moral yang baik di era teknologi dan mampu mempertahankan institusi keluarga sebagai masyarakat mini yang unggul. ${ }^{11}$

Pendidikan tidak lepas dari seorang guru yang menjadi fasilitator untuk anak dalam belajar. Perannya tidak dipungkiri lagi memberikan pengaruh besar bagi perkembangan karakter anak didik. Guru tidak hanya bertugas untuk mentransfer ilmunya tetapi ia juga harus mampu mentransferkan karakter pada anak didiknya, dan tentu saja mentransfer karakter yang baik, bukan malah sebaliknya.

Karakter dapat dikembangkan melalui pengalaman belajar (learning experiences) dan proses pembelajaran yang bermuara pada pembentukan karakter dalam diri individu peserta didik. Proses ini dilaksanakan melalui proses pembudayaan dan pemberdayaan sebagaimana digariskan sebagai salah satu prinsip penyelenggraan pendidikan nasional.

\footnotetext{
${ }^{9}$ rahendra Maya, "Esensi Guru Dalam Visi-Misi Pendidikan Karakter," Edukasi Islami: Jurnal Pendidikan Islam 2, no. 03 (8 Juni 2017).

${ }^{10}$ Anggun Wulan Fajriana dan Mauli Anjaninur Aliyah, "Tantangan Guru Dalam Meningkatan Mutu Pendidikan Agama Islam Di Era Melenial," Nazhruna: Jurnal Pendidikan Islam 2, no. 2 (11 Agustus 2019): 246-265.

11 Sidiq Sekar Ihsan, "Peran Guru Agama Islam Dalam Pembinaan Akhlaq Remaja Di Wilayah Majlis Ta'lim Al Munawwarah Cibubur," SAP (Susunan Artikel Pendidikan) 4, no. 2 (5 Desember 2019), https://doi.org/10.30998/sap.v4i2.4893.
} 
Agus Setiawan: Guru Berkarakter di Era Milenial (Perspektif Habib Abdullah Bin Alawi Al-Haddah)

Dengan guru memiliki nilai, sikap, dan perilaku yang dapat diteladani maka peserta didik bukan hanya memiliki pengertian tentang nilai namun juga pemahaman dan keyakinan akan nilai yang ingin dibentuk karena adanya figur teladan. ${ }^{12}$ Sikap dari seorang guru adalah salah satu faktor yang menentukan bagi perkembangan jiwa anak didik selanjutnya. Karena sikap seorang guru tidak hanya dilihat dalam waktu mengajar saja, tetapi juga dilihat tingkah lakunya dalam kehidupan sehari-hari oleh anak didiknya. ${ }^{13}$

Guru yang berkarakter.Ia bukan hanya memiliki kemampuan yang bersifat intelektual tetapi juga memiliki kemampuan secara emosi dan spiritual sehingga guru mampu membuka mata hati peserta didik untuk belajar, dan selanjutnya mampu hidup dengan baik di tengah-tengah masyarakat.Sosok guru yang berkarakter kuat, diharapkan mampu mengemban amanah dalam mendidik peserta didiknya.Guru harus memiliki kompetensi utama yang harus melekat pada guru.Yaitu nilai-nilai keamanahan, keteladanan, dan mampu melakukan pendekatan pedagogis serta mampu berpikir dan bertindak cerdas. ${ }^{14}$

Di lingkungan sekolah, pendidikan diberikan kepada anak didik dalam waktu terbatas, sehingga terbatas pula waktu bagi para siswa untuk berkomunikasi dan berinteraksi dengan guru. Oleh sebab itu, guru harus berkonsentrasi memberi perhatian kepada kepribadian dan fisik anak didik secara terbatas pula.

Dalam pendidikan karakter, kemampuan untuk melaksanakan dalam tindakan nyata, disertai kemauan dan kebiasaan melakukan moral harus dimunculkan dan ditingkatkan. Dengan demikian tampak jelas bahwa pendidikan karakter diperlukan ketiga unsur pengertian, perasaan, dan tindakan

12 Novia Wahyu Wardhani dan Margi Wahono, "Keteladanan Guru Sebagai Penguat Proses Pendidikan Karakter," Untirta Civic Education Journal 2, no. 1 (30 April 2017), https://doi.org/10.30870/ucej.v2i1.2801.

13 akhmad Busyaeri Dan Mumuh Muharom, "Pengaruh Sikap Guru Terhadap Pengembangan Karakter (Peduli Sosial) Siswa Di Mi Madinatunnajah Kota Cirebon," Al Ibtida: Jurnal Pendidikan Guru MI 2, no. 1 (10 Februari 2016).

${ }^{14}$ Nazaruddin, "Menggagas Sosok Guru Berkarakter Kuat di Era Globalisasi," Jurnal Pendidikan Dompet Dhuafa 6, no. 01 (14 Mei 2016): 12-18. 
Agus Setiawan: Guru Berkarakter di Era Milenial (Perspektif Habib Abdullah Bin Alawi Al-Haddah)

harus ada. Pendidikan karakter yang terlalu fokus pada pengembangan kognitif tingkat rendah, perlu dilengkapi dengan pengembangan kognitif tingkat tinggi sampai subjek didik memiliki keterampilan membuat keputusan moral yang tepat secara mandiri, memiliki komitmen yang tinggi untuk bertindak selaras dengan keputusan moral tersebut, dan memiliki kebiasaan (habit) untuk melakukan tindakan bermoral.

\section{b. Peran Guru PAI dalam Pendidikan Karakter}

Lembaga pendidikan dan guru dewasa ini dihadapkan pada tuntutan yang semakin berat, terutama untuk mempersiapkan anak didik agar mampu menghadapi dinamika perubahan yang berkembang dengan pesat. Perubahan yang terjadi tidak saja berkaitan dengan perubahan ilmu pengetahuan dan teknologi saja, melainkan juga menyentuh tentang pergeseran aspek nilai dan moral dalam kehidupan bermasyarakat. Lingkungan sekolah (guru) saat ini memiliki peran sangat besar pembentukan karakter anak/siswa.

Kehormatan seorang guru adalah bagian dari kepribadiannya yang paling penting dalam mewujudkan tugas profesionalnya. Karena itu, ia harus mampu mengenali dan mengembangkan kebanggaan pribadi ini sebaik mungkin. ${ }^{15}$

Untuk itu kompetensi kepribadian yang ada dalam buku ta`limul muta`allim karya Imam az-Zarnuji harus disadari oleh para pendidik saat ini seperti, serius, menjaga wudhu dan istiqomah sholat malam. ${ }^{16}$ Bentuk perhatian seorang guru kepada siswa dalam bentuk bimbingan, arahan, saran, motivasi belajar dan program yang dapat meningkatkan kecerdasan emosi dan spiritual siswa. ${ }^{17}$

${ }^{15}$ Nursyamsi Nursyamsi, “Pengembangan Kepribadian Guru,” Al-Ta lim Journal 21, no. 1 (1 Maret 2014): 32-41.

${ }^{16}$ Muhammad Anas Ma'arif, "Analisis Konsep Kompetensi Kepribadian Guru PAI Menurut Az-Zarnuji," Istawa: Jurnal Pendidikan Islam 2, no. 2 (2017): 35-60-60.

17 Much Solehudin, "Peran Guru PAI Dalam Mengembangkan Kecerdasan Emosional (Eq) Dan Kecerdasan Spiritual (SQ) Siswa SMK Komputama Majenang," Jurnal Tawadhu 2, no. 1 (18 Oktober 2018): 303-25. 
Agus Setiawan: Guru Berkarakter di Era Milenial (Perspektif Habib Abdullah Bin Alawi Al-Haddah)

Penanaman dan pengembangan pendidikan karakter di sekolah menjadi tanggung jawab bersama. Pendidikan karakter dapat dintegrasikan dalam pembelajaran pada setiap mata pelajaran. Setiap mata pelajaran yang berkaitan dengan norma atau nilai-nilai pada setiap mata pelajaran perlu dikembangkan, dieksplisitkan, dikaitkan dengan konteks kehidupan sehari-hari. Pembelajaran nilai-nilai karakter ini tidak berhenti pada tataran kognitif, tetapi menyentuh pada tataran internalisasi, dan pengamalan nyata dalam kehidupan anak didik sehari-hari di masyarakat.

Sama halnya pemikiran al-Ghazali dan al-Zarnuji diserap secara positif dan responsif oleh pemerintah Indonesia untuk membangun karakter nasional yang diimplementasikan secara luas dalam kurikulum nasional berdasarkan kearifan lokal dan nilai-nilai Islam. ${ }^{18}$ Secara teoritis Said pemikiran Nursi didasarkan pada al-Qur'an as-Sunnah dan dalam praktiknya dapat memberikan nilai spiritual melalui akal dan akhlak sehingga diharapkan dapat mengubah masyarakat menjadi bermoral dalam kehidupan sehari-hari, baik di sekolah maupun di rumah. ${ }^{19}$ Kepribadian PAI pedoman yang harus dimiliki oleh seorang guru oleh ulama sebelumnya untuk menjadikannya sebagai sosok guru yang ideal. ${ }^{20}$

Berkaitan dengan tiga tugas tersebut dengan pendidikan karakter, budaya, dan moral bagi bangsa Indonesia, secara prinsip sudah ditetapkan baik dalam UUD 1945 maupun dalam Undang-Undang Sisdiknas no 20 tahun 2003. Kurikulum disusun sesuai dengan jenjang pendidikan dalam kerangka Negara Kesatuan Republik Indonesia dengan memperhatikan secara keseluruhan.

${ }^{18}$ Agus Setiawan, "Prinsip Pendidikan Karakter Dalam Islam (Studi Komparasi Pemikiran Al-Ghazali dan Burhanuddin Al-Zarnuji)," Dinamika Ilmu 14, no. 1 (2014): $1-12$.

19 Agus Setiawan, "Relevansi Pendidikan Akhlak di Masa Modern Perspektif Bediuzzaman Said Nursi," Syamil 4, no. 2 (2016): 105-128.

${ }^{20}$ Khoerotun Ni'mah, "Konsep Kompetensi Kepribadian Guru PAI," Jurnal Pendidikan Agama Islam 11, no. 1 (2 Juni 2014): 79-94. 
Agus Setiawan: Guru Berkarakter di Era Milenial (Perspektif Habib Abdullah Bin Alawi Al-Haddah)

Penyelenggaraan PAI berhubungan dengan pencapaian tujuan keimanan, ketakwaan, dan akhlak mulia berdasarkan semangat UU RI Nomor 20 tahun 2003 tentang Sistem Pendidikan Nasional. Dalam pencapaian mutu PAI dalam konteks nasional memerlukan pemahaman mengenai paradigma pengembangan PAI. Paradigma ini menjadi landasan dalam pengembangan strategi pengembangan mutu PAI. ${ }^{21}$

Sekolah merupakan wahana pengembang pendidikan karakter memiliki peranan yang sangat penting. Guru dan pendidik mempunyai tanggung jawab yang sangat besar dalam menghasilkan generasi yang berkarakter, berbudaya, dan bermoral. Guru merupakan teladan bagi siswa dan mempunyai peran yang sangat besar dalam pembentukan karakter siswa. Undang-undang no. 14 tahun 2005 tentang Guru dan Dosen menyatakan bahwa guru sebagai pendidik professional mempunyai tugas utama mendidik, mengajar, membimbing, mengarahkan, melatih, menilai, dan mengevaluasi peserta didik pada pendidikan anak usia dini, pada jalur pendidikan formal, pendidikan dasar, dan pendidikan menengah.

Dengan demikian semakin jelas bahwa peran guru dalam dunia pendidikan sekarang ini semakin meningkat, kompleks, dan berat. Sisi lain memberikan wacana bahwa guru bukan hanya pendidik akademis, tetapi juga pendidik karakter, pendidik budaya, dan pendidik moral bagi para peserta didiknya.

\section{c. Guru Berkarakter Menciptakan Bangsa yang Berkarakter}

Sebelum masuk pada pembahasan implementasi karakter Salik dalam Guru, sebaiknya kita mengetahui hasil Sarasehan Nasional Pendidikan Budaya dan Karakter Bangsa. Hal ini yang selanjutnya menghasilkan sebuah Kesepakatan Nasional Pengembangan Pendidikan Budaya dan Karakter Bangsa yang dinyatakan sebgai berikut:

${ }^{21}$ Rudi Ahmad Suryadi, "Visi dan Paradigma Pendidikan Agama Islam (PAI): Kualitas, Integratif, dan Kompetitif," EDUKASI: Jurnal Pendidikan Islam 4, no. 2 (1 November 2016): 253-76. 
Agus Setiawan: Guru Berkarakter di Era Milenial (Perspektif Habib Abdullah Bin Alawi Al-Haddah)

1. Pendidikan budaya dan karakter bangsa merupakan bagian integral yang tidak terpisahkan dari pendidikan nasional secara utuh.

2. Pendidikan budaya dan karakter bangsa harus dikembangkan secara komperhensif sebagai proses pembudayaan. Oleh karena itu, pendidikan dan kebudayaan secara kelembagaan perlu diwadahi secara utuh.

3. Pendidikan budaya dan karakter bangsa merupakan tanggung jawab bersama antara pemerintah, masyarakat, sekolah, dan orang tua. Oleh karena itu, pelaksanaan pendidikan budaya dan karakter bangsa harus melibatkan keempat unsur tersebut.

4. Dalam upaya merevitalisasi pendidikan budaya dan karakter bangsa diperlukan gerakan nasional guna menggugah semangat kebersamaan dalam pelaksanaan di lapangan.

Kemudian bagaimana implementasi pendidikan karakter di Indonesia. Menurut Kementrian Pendidikan Nasional, pendidikan karakter harus meliputi dan berlangsung pada. 1). Pendidikan Formal, sekolah, 2). Pendidikan Nonformal, seperti lembaga kursus dll, 3). Pendidikan Informal, yaitu keluarga. $^{22}$

\section{Kesimpulan}

Guru yang berkarakter Islami menurut al-Habib Abdullah bin Alawi AlHaddad yaitu mengarah pada pembersihan diri seseorang. Melingkupi niat, taubat, menahan anggota tubuh dari maksiat, selalu dalam keadaan suci, menjauhi maksiat dan mengerjakan perintah, menjaga shalat, jangan meninggalkan jamaah dan jumah, banyak berdzikir dan bertafakur, bila datang rasa malas, tentang sabar dan syukur, bila dalam keadaan kekurangan harta, dihina orang, menghindari takut dan tamak pada makhluk, larangan mencari mukasyafah, tawakal, berkumpul dengan orang baik.

${ }^{22}$ Muchlas Samani dan Hariyanto, Konsep dan Model Pendidikan Karakter (Bandung: Remaja Rosdakarya, 2016), h. 19-20. 
Agus Setiawan: Guru Berkarakter di Era Milenial (Perspektif Habib Abdullah Bin Alawi Al-Haddah)

Adapun pengimplementasian karakter guru dalam pemikiran al-Habib Abdullah bin Alawi Al-Haddad yaitu pertama yang diperbaiki adalah niat, kedua perlunya pertobatan itu meliputi pada semua orang dan keadaan tidak ada seorang pun yang terkecualikan, ketiga menjaga anggota tubuh dari maksiat dan fitnah dunia, keempat selalu dalam keenam menghadap Allah dan meluangkan waktu untuk beribadah, ketujuh selalu dzikir dan tafakur, kedelapan tidak malas dalam ketaatan dan cenderung melanggar, kesembilan yaitu sabar, rizqi telah dibagi, sabar atas celaan manusia dan fitnahnya, kesepuluh yaitu membuang nilai diawasi oleh makhluk, dan terakhir kesebelas berteman dengan orang baik.

Akhirnya, bahwa pemikiran al-Habib Abdullah bin Alawi Al-Haddad dalam kitabnya telah memberikan telaah lengkap bagi seorang guru untuk berpedoman pada kesucian diri sehingga akan lahir jiwa guru yang berkarakter Islami. Terlebih pada era milenial saat ini diperlukan guru yang memiliki karakter kuat agar menciptakan generasi anak bangsa yang berkarakter pula sehingga apa yang dimuat dalam UU Sisdiknas No 20 Tahun 2013 mengenai generasi berkarakter akan terlaksana sesuai cita-cita bangsa. 
Agus Setiawan: Guru Berkarakter di Era Milenial (Perspektif Habib Abdullah Bin Alawi Al-Haddah)

\section{Daftar Pustaka}

A, Doni Koesoema. Pendidikan Karakter: Strategi Mendidik Anak di Zaman Global. Jakarta: Grasindo, 2007.

Baharun, Al-Habib Ali bin Hasan. al-Fawaid al-Mukhtarah lii Saliik Thariiqi al-Akhirah. Bangil: Ma'had Darul Lhuggah, 2008.

Busyaeri, Akhmad, dan Mumuh Muharom. "Pengaruh Sikap Guru Terhadap Pengembangan Karakter (Peduli Sosial) Siswa Di Mi Madinatunnajah Kota Cirebon." Al Ibtida: Jurnal Pendidikan Guru MI 2, no. 1 (10 Februari 2016).

Fajriana, Anggun Wulan, dan Mauli Anjaninur Aliyah. "Tantangan Guru Dalam Meningkatan Mutu Pendidikan Agama Islam Di Era Melenial." Nazhruna: Jurnal Pendidikan Islam 2, no. 2 (11 Agustus 2019): 246-65.

Haddad, Al-Habib Abdullah bin Alawi al-. Risalah Mu'awanah Terj Ahmad Yunus al-Muhdhar Nasehat untukmu Wahai Saudaraku. Surabaya: Cahaya Ilmu, 2015.

Ihsan, Sidiq Sekar. "Peran Guru Agama Islam Dalam Pembinaan Akhlaq Remaja Di Wilayah Majlis Ta'lim Al Munawwarah Cibubur." SAP (Susunan Artikel Pendidikan) 4, no. 2 (5 Desember 2019). https://doi.org/10.30998/sap.v4i2.4893.

Ma'arif, Muhammad Anas. "Analisis Konsep Kompetensi Kepribadian Guru PAI Menurut Az-Zarnuji." Istawa: Jurnal Pendidikan Islam 2, no. 2 (2017): 35-60-60.

Maya, Rahendra. "Esensi Guru Dalam Visi-Misi Pendidikan Karakter." Edukasi Islami: Jurnal Pendidikan Islam 2, no. 03 (8 Juni 2017).

Nawawi, Imam. al-Arba'in Nawawiyah Terj Yunan Abduh Hadis ar-Arba;in Annawawiyah. Surakarta: Media Insani, 2007.

Nazaruddin, S. PdI. "Menggagas Sosok Guru Berkarakter Kuat Di Era Globalisasi." Jurnal Pendidikan Dompet Dhuafa 6, no. 01 (14 Mei 2016): $12-18$.

Ni'mah, Khoerotun. "Konsep Kompetensi Kepribadian Guru PAI." Jurnal Pendidikan Agama Islam 11, no. 1 (2 Juni 2014): 79-94.

Nursyamsi, Nursyamsi. "Pengembangan Kepribadian Guru." Al-Ta lim Journal 21, no. 1 (1 Maret 2014): 32-41. 
Agus Setiawan: Guru Berkarakter di Era Milenial (Perspektif Habib Abdullah Bin Alawi Al-Haddah)

Qaimmuddin. Durrarul Muhammadiyah. Bangil: Dalwa, 2010.

Samani, Muchlas, dan Hariyanto. Konsep dan Model Pendidikan Karakter. Bandung: Remaja Rosdakarya, 2016.

Setiawan, Agus. "Prinsip Pendidikan Karakter Dalam Islam (Studi Komparasi Pemikiran Al-Ghazali dan Burhanuddin Al-Zarnuji).” Dinamika Ilmu 14, no. 1 (2014): 1-12.

- "Relevansi Pendidikan Akhlak di Masa Modern Perspektif Bediuzzaman Said Nursi.” Syamil 4, no. 2 (2016): 105-128.

Smith, Al-Habib Zein bin Ibrahim bin. al-Mahajus Sawi. Tarim Hadramaut: Darul Fatah, 2008.

Solehudin, Much. "Peran Guru Pai Dalam Mengembangkan Kecerdasan Emosional (EQ) dan kecerdasan spiritual (SQ) Siswa Smk Komputama Majenang." Jurnal Tawadhu 2, no. 1 (18 Oktober 2018): 303-25.

Sugiyono. Metode Penelitian \& Pengembangan (Research and Development). Bandung: Alfabeta, 2017.

Suryadi, Rudi Ahmad. "Visi Dan Paradigma Pendidikan Agama Islam (Pai): Kualitas, Integratif, Dan Kompetitif." EDUKASI: Jurnal Pendidikan Islam 4, no. 2 (1 November 2016): 253-76.

Wardhani, Novia Wahyu, dan Margi Wahono. "Keteladanan Guru Sebagai Penguat Proses Pendidikan Karakter." Untirta Civic Education Journal 2, no. 1 (30 April 2017). https://doi.org/10.30870/ucej.v2i1.2801. 